ЕЖОВ Дмитрий Александрович - кандидат политических наук, доцент; доцент департамента политологии факультета социальных наук и массовых коммуникаций Финансового университета при Правительстве РФ (125993, Россия, г. Москва, ГСП-3, Ленинградский пр-кт, 49; president@ lenta.ru)

\title{
ВЫБОРЫ ДЕПУТАТОВ ГОСУДАРСТВЕННОЙ ДУМЫ РОССИЙСКОЙ ФЕДЕРАЦИИ ВОСЬМОГО СОЗЫВА: ТЕНДЕНЦИИ И ПРОГНОЗЫ
}

\begin{abstract}
Аннотация. В статье выявляются тенденции, характеризующие ход кампании по выборам депутатов Государственной думы Российской Федерации восьмого созыва и формирующие ее проблемный фон. На основе анализа распространившихся в экспертном сообществе сценариев выборов в нижнюю палату парламента России в 2021 г. и оценки текущей политической конъюнктуры формируется авторское прогнозное суждение относительно исхода избирательной кампании.
\end{abstract}

Ключевые слова: выборы, политические партии, Государственная дума, предвыборная кампания, сценарное прогнозирование

П риближение запланированных на сентябрь 2021 г. выборов депутатов Государственной думы Российской Федерации восьмого созыва обусловливает актуальность анализа тенденций, задающих тон предвыборной кампании, и выработки прогностических суждений относительно ее возможного исхода. В качестве тенденций, сопровождающих ход кампании, целесообразно рассматривать состояние пандемии коронавируса COVID-19 и преодоления ее последствий, формирующее проблемный фон, вокруг которого с высокой долей вероятности будет выстраиваться предвыборная риторика политических партий, допущенных к участию в выборах, и кандидатов в одномандатных округах, а также трансформацию партийно-политического спектра, ставшую следствием процессов в области партийного строительства. Прогностические суждения относительно потенциальной конфигурации депутатского корпуса нового созыва представляется оправданным строить на основе сценарных прогнозов, обнародованных представителями экспертного сообщества в преддверии кампании.

Пандемия коронавируса COVID-19 внесла существенные коррективы во все сферы жизнедеятельности общества и в т.ч. стимулировала пересмотр подходов политических акторов к организации их взаимодействия с электоратом, что практически выразилось в стремлении к совершенствованию интернеткоммуникаций партий [Бродовская 2020], обусловленному объективно выраженным усилением эффекта влияния цифровых коммуникаций на политическое участие [Пырма 2019]. Анализ персонального состава пула потенциальных кандидатов, зарегистрировавшихся для участия в праймериз партии «Единая Россия», свидетельствует о присутствии среди них лиц, прямо или косвенно ассоциирующихся с активностью по преодолению последствий пандемии (волонтеры, медики и т.д.). В условиях текущего электорального цикла вследствие кардинального изменения информационной повестки произошла содержательная трансформация тенденций избирательного процесса в России, характерных для периода федеральных выборов 2016 г. [Ежов 2016], сформированных в т.ч. под воздействием «крымского консенсуса» [Шатилов 2015] и роста патриотических настроений [Шатилов 2017]. Таким образом, можно констатировать, что тема борьбы с пандемией и преодоления ее последствий 
становится центральной темой кампании 2021 г., определяя содержательную составляющую межпартийного диалога в ходе предвыборной конкуренции, несомненное преимущество в которой имеют акторы, в наибольшей степени проявившие себя с положительной стороны в период самоизоляции (в т.ч. в организации волонтерской деятельности) и сумевшие адаптироваться к новым условиям, требующим активизации онлайн-практик во взаимодействии с избирателями.

Тренд, практически выразившийся в актуальных событиях в области партийного строительства, а именно в появлении на политической арене новых партий с относительно низкими стартовыми электоральными позициями при их рассмотрении в качестве самостоятельных игроков и воспринимаемых в качестве потенциального ресурса для увеличения базы поддержки парламентских партий путем тактического объединения [Ежов 2021], уже получил развитие вследствие создания коалиции на базе партии «Справедливая Россия» с участием учрежденной в 2020 г. партии «За Правду», а также существовавшей ранее малой партии «Патриоты России». Таким образом, на фоне текущих событий происходит упорядочивание партийно-политического спектра современной России. Дополнительную интригу в ход кампании добавляет явно наметившаяся борьба за второе место на выборах между партиями парламентской оппозиции. Однако, несмотря на декларируемые представителями образованной коалиции претензиями на получение статуса второй политической силы страны, представляется очевидным, что основными претендентами на второе место по итогам выборов в Государственную думу восьмого созыва являются КПРФ и ЛДПР, нуждающиеся в ребрендинге и значительном кадровом обновлении в перспективе последующих электоральных циклов.

Выработка суждений прогностического характера относительно потенциальных результатов выборов в Государственную думу в сентябре 2021 г. в целом сводится к обсуждению нескольких сценариев. Так, в аналитическом докладе АПЭК, опубликованном в марте 2021 г., с вероятностью в $50 \%$ прогнозируется реализация инерционного сценария, предполагающего сохранение четырехпартийной модели, основанной на прохождении в парламент четырех парламентских партий - «Единой России», КПРФ, ЛДПР и «Справедливой России» с учетом трендов, рассмотренных нами выше. Институционализация новой партийной фракции в качестве основы альтернативного сценария менее вероятна и оценивается экспертами в $35 \%$. Формирование в результате выборов трехпартийной модели, исключающей шансы обновленной партии «Справедливая Россия» на преодоление 5-процентного барьера, еще менее вероятно и оценивается в пределах $10 \%$. Утопический сценарий сводится к формированию полноценной многопартийной модели 1 . Чуть ранее, в феврале 2021 г., эксперты фонда «Петербургская политика» описали три возможных сценария выборов в Государственную думу: «Крепость», который предполагает получение «Единой Россией» конституционного большинства; «Ветер перемен», допускающий формирование большинства «Единой Россией» и прохождение в новый состав парламента какой-либо из малых партий; «Ускользающее большинство», в основе которого лежит реализация идеи снижения степени контроля над выборами ${ }^{2}$.

\footnotetext{
1 Парламентская кампания-2021: риски хаотизации и базовые сценарии. - Агентство политических и экономических коммуникаций. Доступ: http://www.apecom.ru/projects/item. php?SECTION_ID=91\&ELEMENT_ID=6971 (проверено 30.03.2021).

2 Выборы в новую или старую Госдуму: Динамика versus инерция: что страшнее? Фонд «Петербургская политика». Доступ: https://fpp.spb.ru/review-gd-elections (проверено 30.03.2021).
} 
Учитывая совокупность экспертных мнений, текущее состояние политической конъюнктуры, а также направление общественного запроса и характер электоральных настроений, находящихся в динамике, обусловленной определенными выше тенденциями, полагаем оправданным в качестве наиболее вероятного сценария рассматривать сохранение по итогам выборов 2021 г. четырехфракционной нижней палаты парламента с большинством партиилидера в лице «Единой России», представительством системной оппозиции в лице КПРФ, ЛДПР и «Справедливой России - За Правду». В то же время не исключено, что в состав нового депутатского корпуса вне фракций смогут войти отдельные депутаты, избранные по одномандатным округам от партий, не преодолевших 5-процентный барьер. Таким образом, будет сконструирована модель депутатского корпуса, по параметрам и формальным характеристикам соответствующая конфигурации, воплощенной в функционировании Государственной думы седьмого созыва.

\section{Список литературы}

Бродовская Е.В. 2020. Цифровой менеджмент в деятельности российских политических партий: проблемное поле управления информационными потоками в социальных медиа. - Власть. Т. 28. № 6. С. 81-88.

Ежов Д.А. 2016. К проблеме определения тенденций современного избирательного процесса в России. - Власть. Т. 24. № 7. С. 35-38.

Ежов Д.А. 2021. Выборы-2021: к оценке электоральных перспектив новых политических партий. - Азимут научных исследований: экономика и управление. T. 10. № 1(34). C. 32-34.

Пырма Р.В. 2019. Влияние цифровых коммуникаций на политическое участие. - Гуманитарные науки. Вестник Финансового университета. Т. 9. № 4(40). C. 63-69.

Шатилов А.Б. 2015. «Крымский консенсус» российской элиты: причины и последствия. - Гуманитарные науки. Вестник Финансового университета. № 2(18). С. 6-13.

Шатилов А.Б. 2017. Формирование концепта государственного патриотизма в России в период 2000-2017 гг:: основные этапы и базовые идеологемы. Гуманитарные науки. Вестник Финансового университета. Т. 7. № 3(27). С. 18-23.

EZHOV Dmitriy Aleksandrovich, Cand.Sci. (Pol.Sci.), Associate Professor; Associate Professor of the Department of Political Science, Faculty of Social Sciences and Mass Communications, Financial University under the Government of the Russian Federation (49 Leningradsky Ave, GSP-3, Moscow, Russia, 125993; president@lenta.ru)

\section{ELECTIONS OF DEPUTIES OF THE STATE DUMA OF THE RUSSIAN FEDERATION OF THE EIGHTH CONVOCATION: TRENDS AND FORECASTS}

\footnotetext{
Abstract. The article reveals the trends that characterize the course of the campaign for the election of deputies of the State Duma of the Russian Federation of the eighth convocation and form its problematic background. Based on the analysis of the scenarios of the elections to the lower house of the Russian Parliament in 2021 that have spread in the expert community and the assessment of the current political situation, the author's forecast judgment regarding the outcome of the election campaign is formed.

Keywords: elections, political parties, State Duma, election campaign, scenario forecasting
} 